\title{
Innovative rock support under flowing water conditions in underground caverns
}

\author{
Saikat Pal, G Kannan, Ranjit Rath and Atul Nanda \\ Engineers India Limited \\ New Delhi, India \\ saikat.pal@eil.co.in
}

\begin{abstract}
Underground construction of tunnels and caverns is an ever challenging project by virtue of the likelihood of encountering uncertain ground conditions. This is true despite all advancement in the field of prediction tools, equipment and instrumentation. One major factor leading to such uncertainties is ground water ingress during underground excavation. The excavation and installation of primary rock supports under flowing water condition is a significant challenge. This is even more difficult for storage cavern where apart from instability due to ground water, water loss through excavated segments, hinders the groundwater table conservation and threatens the basic premise of a saturated rockmass surrounding the storage cavern. Located in the Peninsular gneissic complex on west coast of India, the underground rock cavern under consideration has a geological setting comprising 2 to 3 sets of sub vertical and one set sub-horizontal joint set. Some of these cited joint sets were observed to be permeable and acted as water conduit during excavation. Owing to a saturated rockmass above, the uncontrolled water flow through these joints hindered the rock support installation process, particularly as significant leakage from the drilled holes for the rock bolts. In order to counter the problem, an innovative method of support to rockmass as well as grouting the surrounding rock mass was used by using mechanical packers with rebars. This indigenous method, with existing logistics, helped to successfully handle rock support under the flowing water seepage conditions, without any additional cost implication to project in this regard.
\end{abstract}

The present paper outlines the detail methodology of installation of improvised rock bolts to deal with rock support in zones of water ingress.

Keywords-groundwater ingress; storage cavern; rock support; grouting; mechanical packer

\section{INTRODUCTION}

In unlined underground rock caverns excavated for storage of crude oil, the product is kept confined within caverns by principle of hydrodynamic containment (Amantini et al 2005) wherein the natural ground water potential towards caverns is enhanced by artificial recharging. The recharging is done by making small dimension galleries above the cavern and water charging boreholes drilled from gallery (Fig. 1). This is known as water curtain system. Water, incoming through permeable rock joints, prevents crude from escaping through the joints.

In the field of underground space technology, continuous advancements are made with respect to ground prediction techniques, equipment and instrumentation.

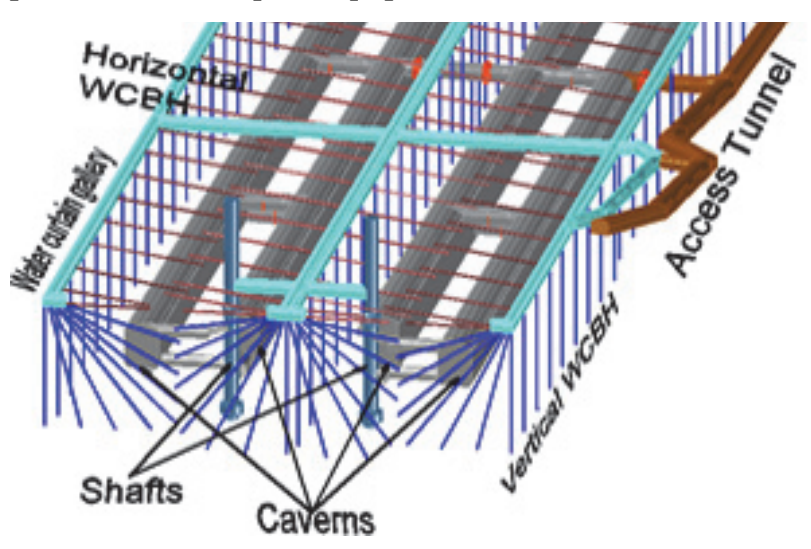

Fig. 1 Layout of the project

However, under- ground construction of tunnels and caverns are challenging job by virtue of uncertain ground conditions. Ground water ingress during excavation is one of the major uncertainties.

The permeability varies over wide range. The seepage water affects the stability and deformation of tunnel by reducing the effective stress and thereby resistance to shearing, generates seepage forces towards excavation boundary and may lead to draw down of water table (Anagnostou 2006).

In case of storage cavern, the effects of ground water ingress are fourfold:

1. Instability of structures due to ground water: similar to all other forms of underground excavation.

2. Ineffective hydrodynamic containment: water loss through excavated areas, hinders the groundwater table conservation and threatens the de-saturation of rock mass.

3. Increase in water curtain intake.

4. Increase in seepage quantity with respect to Design dewatering pump capacity. The excavation and rock 
supporting under flowing water condition is herculean task. This is more so for storage cavern where apart from instability due to ground water, water loss through excavated areas, hinders the groundwater table conservation and threatens the de-saturation of rock mass - a condition where rock mass is depleted of water. Such condition has to be prevented to maintain the safe storage principle.

\section{PROJECT HYDRO-GEOLOGICAL MODEL}

The underground rock cavern under consideration is located in the granitic gneiss belonging to the Peninsular Gneissic complex of Archaean age), characterized by strong granitic gneiss with 2-3 sets of sub vertical and a set subhorizontal joint. The host rock has been intruded by dolerite dykes of variable orientation and thickness. The permeability of the gneissic rock is very low of the order of $10^{-9} \mathrm{~m} / \mathrm{sec}$ but some joints showed permeability in the range from $10^{-8}$ to $10^{-6} \mathrm{~m} / \mathrm{sec}$ and locally very high permeability of the order of $10^{-4} \mathrm{~m} / \mathrm{sec}$. The contacts of dolerite dykes had permeability of the order of $10^{-6}$ to $10^{-7} \mathrm{~m} / \mathrm{sec}$ (Pal et al 2014). These permeable joints acted as water carrier during underground excavation. During excavation, the hydrogeological model was constantly updated by.

- Structural projections of permeable features

- Updating probing and grouting detail

- Updating the seepage points

- Updating permeability values of all $\mathrm{WCBH}$ and manometer holes drilled from underground

\section{- Correlating all above data}

Under normal situation, the potential water bearing zones were identified by probe holes drilled from tunnel front ahead of the tunnel and the water ingress were controlled through pre-excavation treatment like pregrouting: a process where holes are drilled ahead of tunnel and injected with grout mix to form an umbrella of grout around excavated structure.

However, at some instances the horizontal joints near to tunnel periphery could not be predicted by probe holes along tunnel alignment and were exposed on excavation or drilling for rock support (Fig 2.). In some instances, particularly in case of highly permeable sub horizontal (Fig 3 ) or tunnel parallel sub-vertical features, the heavy water inflow could not be totally controlled by pre excavation grouting. In both cases, the uncontrolled water seepage hindered the process of rock support installations, particularly as leakage from rock bolt holes (Fig 4).

\section{PROPOSED ROCK SUPPORT IN WATER BEARING STRATA}

The rock support designed for the caverns essentially comprised of rock bolts and fibrecrete. It was anticipated that some of the bolts would be required to be installed in water bearing strata. In such cases water leaks have to be treated before installing conventional rock bolts as the water flow may wash the sealing material before it sets, jeopardizing the rock bolt strength and qualities.

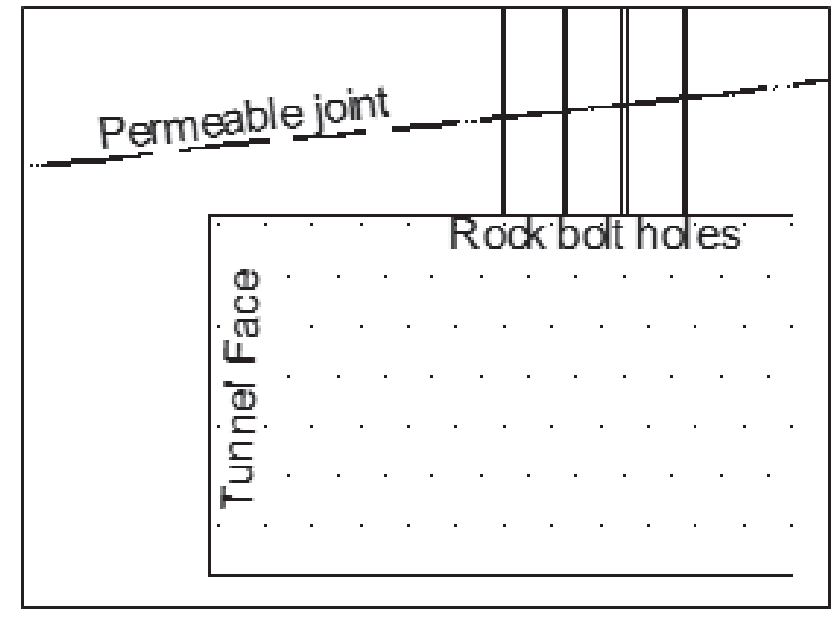

Fig. 2 Permeable joints intersected by rock bolts

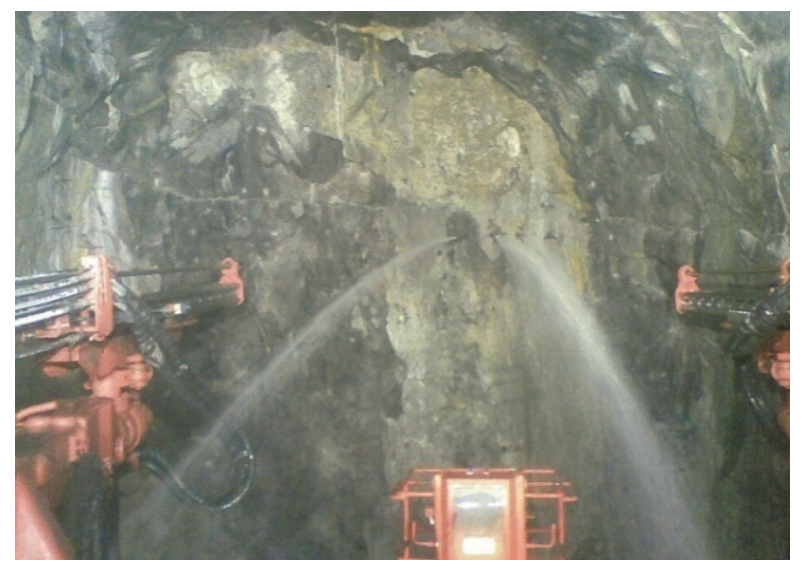

Fig.3. Heavy water ingress through horizontal joints

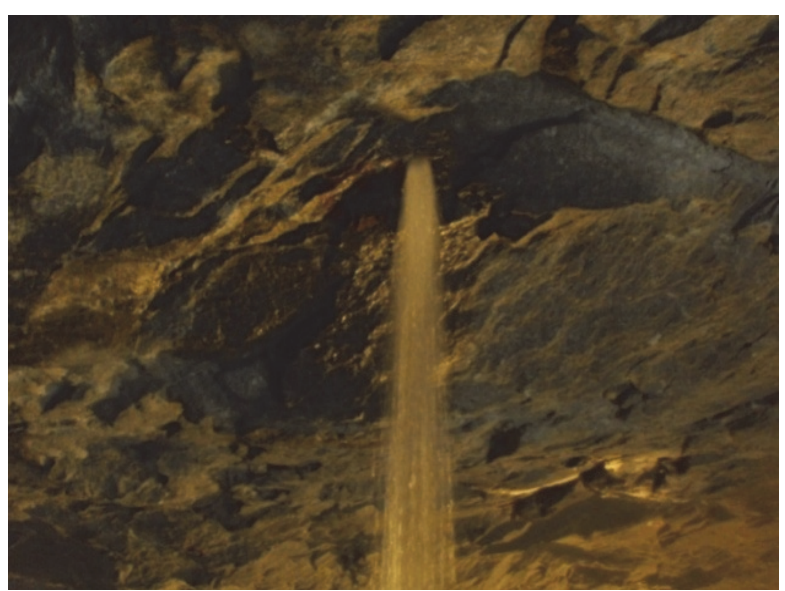

Fig.4. Water inflows from rock bolt hole

Different technical possibilities were specified for rock bolting in water bearing zone:

Hole grouting before inserting the bar.

$>$ Installation of Packer bolts allowing grouting and sealing in one operation.

Installation of CT bolts -or similar - which are basically "groutable anchor bolts". 
The packer bolts are characterised by:

- In built Packer to seal the hole.

- Injection and evacuation tube arrangement.

- Polypropylene sleeve as corrosion protection cover.

- It may also have an expansion shell for endpoint anchorage.

Continuous grouting could be done until the final pressure is reached. The bolt is fully grouted when grout mixture flows out from the air evacuation tube before it is closed. The surrounding rock mass could also be grouted through these by applying suitable grout mix and pressure.

The CT bolt consists of expansion shell providing mechanical anchorage at endpoint, polypropylene sleeve as corrosion protection cover, and a special hemispherical dome at the end, which serves as a grouting chamber. The CT-Bolt is combination of mechanical bolt, installed as a temporary rock support and later grouted to become permanent. The mechanical anchorage takes the initial load. So the post grouting can be taken up later behind working face.

For the project under consideration, the following approach was proposed to install rock bolts in water bearing sections of caverns/tunnels:

Install packer and measure seepage $(\mathrm{Q})$.

i.If $\mathrm{Q}<0.1$ litre/minute: backfill with thick cement or install bolt with resin capsule.

ii.If $\mathrm{Q} 0.1<\mathrm{Q}<1$ litre/minute: grout the hole and ream the hole or drill new hole nearby for rock bolt installation.

iii.Q $>1$ litre/minute in several holes in same tunnel section: substantial treatment (post grouting of area) and then installation of rock bolt.

\section{DifFICUlTIES AND CONSTRAINTS OF ROCK SUPPORT UNDER FLOWING CONDITIONS}

The aforesaid approach encountered serious difficulties for segments with major water seepage i.e. more than one permeable joints were sub parallel/interconnected forming a network and water leaking from an entire zone instead of certain specific holes. The following hindrances were observed:

The new hole drilled was also found leaking.

The leakage from multiple rock bolt holes lead to drawdown of ground water.

The quantum if work increased as grouting of leaking hole had to be completed before rock bolt installation in new hole.

The above constraints along with the migration of water seepage to other holes during grouting of leaking holes posed serious problems:

- The delay in rock support in water bearing zones.

- The ground water table was found affected due to leaking bolts.
- The separate efforts for rock bolting and grouting involving manpower and equipment hampered progress.

The options of using specialized bolts like Packer bolts and/or CT bolts though could considered to be a solution but had associated constraints as under:

$\checkmark$ These are highly expensive.

Not available in India; thus need to be imported with significant time and cost implications.

\section{INNOVATIVE SUPPORT}

View above, an alternative method for rock bolt installation in water seepage zones was conceived. The procedure named "Packer + bolt" was worked out with following schedule of activities.

1. In case of leaking holes, holes to be extended about $0.5 \mathrm{~m}$ longer to accommodate mechanical packers at hole head.

2. The bar to be inserted in hole and kept in place by using centralizers/slightly bending the bar.

3. Mechanical packer with gate valve to be installed at hole head.

4. Grout mix to be prepared with Water/Cement: 0.5 to 0.7 and added with fluidizer

5. Holes to be grouted, with pressure between 5 to 15 bar.

6. The valve of packer to be closed and allowed for curing.

7. Cutting projected packers.

The detailed work flow of method is has been in illustrated below (Fig.5). The installations are shown in the photographs (Fig. 6a and 6b).

The detail of packer + a bolt used in the project is summarized in table 1 below:

TABLE I. DETAILS OF PACKER + BOLTS

\begin{tabular}{|c|c|c|c|c|}
\hline \multirow{2}{*}{$\begin{array}{c}\text { Numbers } \\
\text { of bolts } \\
\text { installed } \\
\text { (nos.) }\end{array}$} & \multirow{2}{*}{$\begin{array}{c}\text { Length } \\
\text { of bolts } \\
\text { (m) }\end{array}$} & \multirow{2}{*}{$\begin{array}{c}\text { Maximum } \\
\text { seepage from a } \\
\text { hole (litre/min) }\end{array}$} & \multicolumn{2}{|c|}{$\begin{array}{c}\text { Grout Intake } \\
\text { (litres) }\end{array}$} \\
\cline { 4 - 5 } & & & $\begin{array}{c}\text { Max in a } \\
\text { hole }\end{array}$ & $\begin{array}{c}\text { Total } \\
\text { volume }\end{array}$ \\
\hline 966 & 3 to 6 & 54 & 760 & $46,297.6$ \\
\hline
\end{tabular}

The process packer and bolts facilitated rock support in water bearing zone in following ways:

$\checkmark$ The installation of rock bolts and grouting of surrounding rock mass in one go.

Minimized time of supporting water bearing zone and enhanced progress.

Method involved logistic support already available at site.

$\checkmark$ No additional work/extra item was called for. 


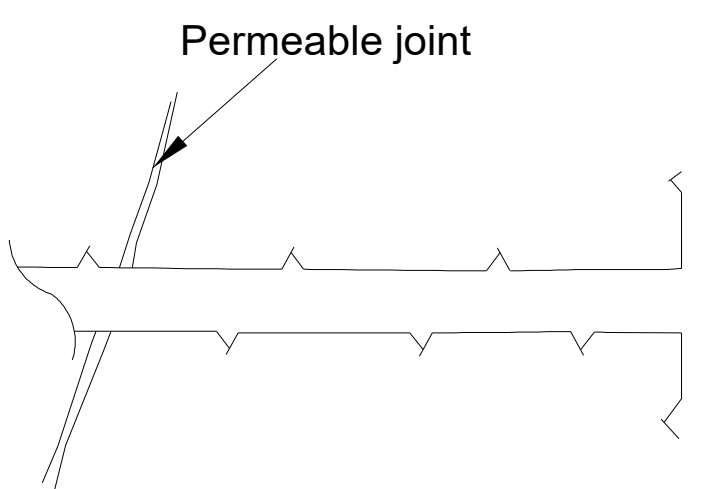

1. Drilling of hole $50 \mathrm{~cm}>R / B$ length
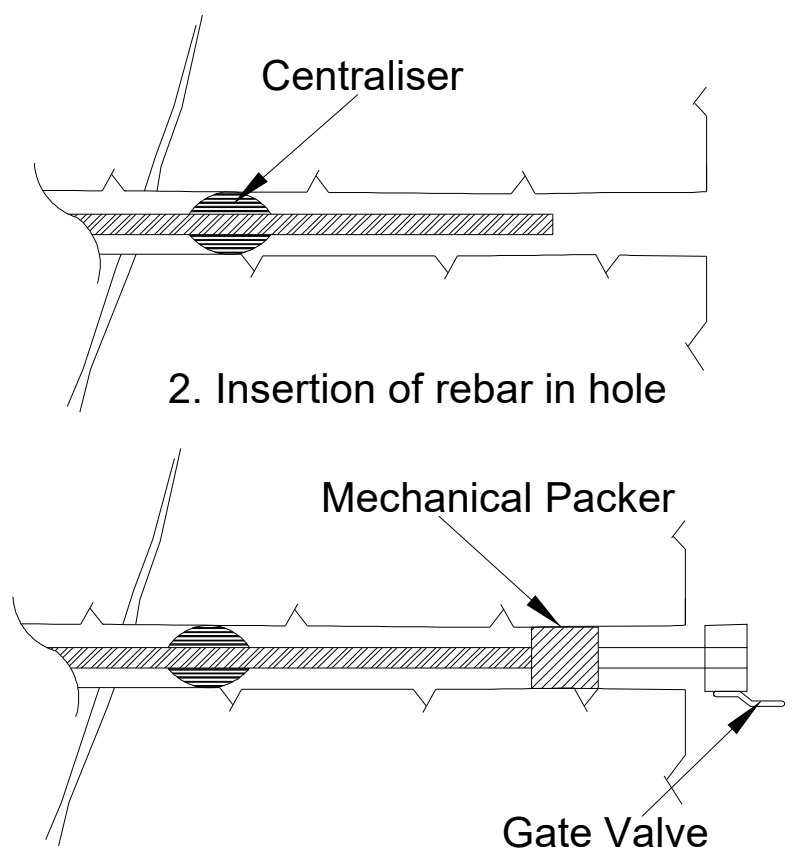

\section{Installation of mechanical packer}

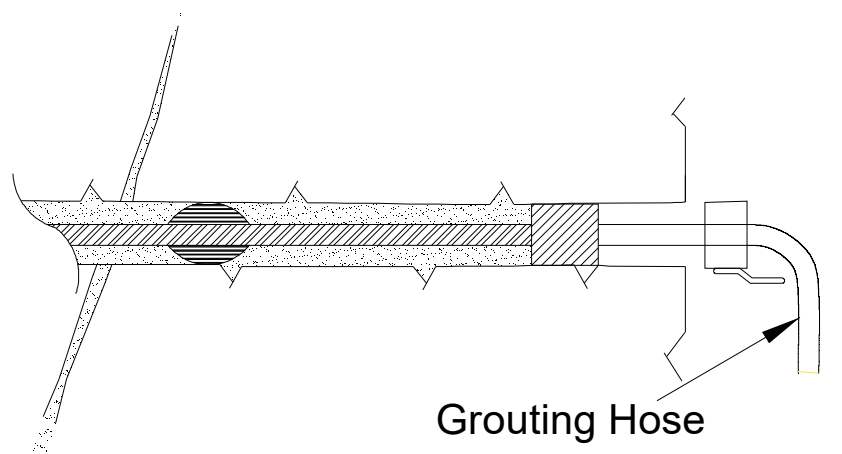

\section{Injection of grout}

Fig.5. Work flow of Packer and bolt installation

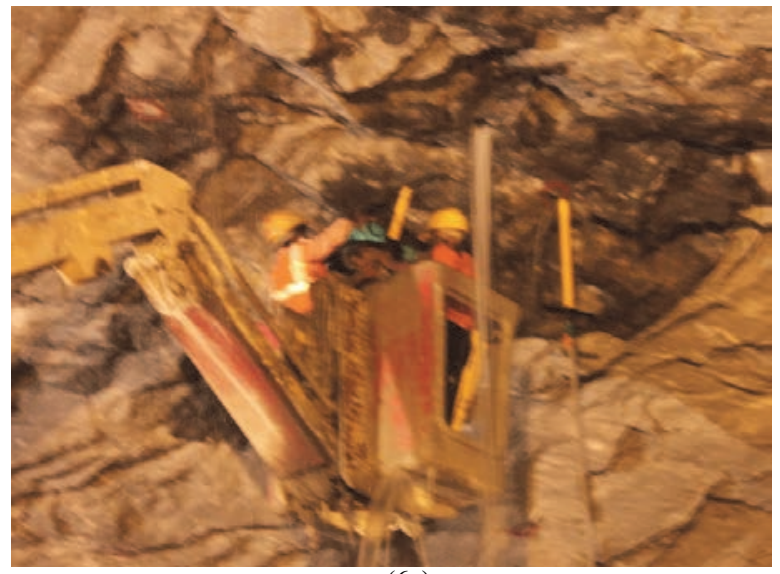

(6a)

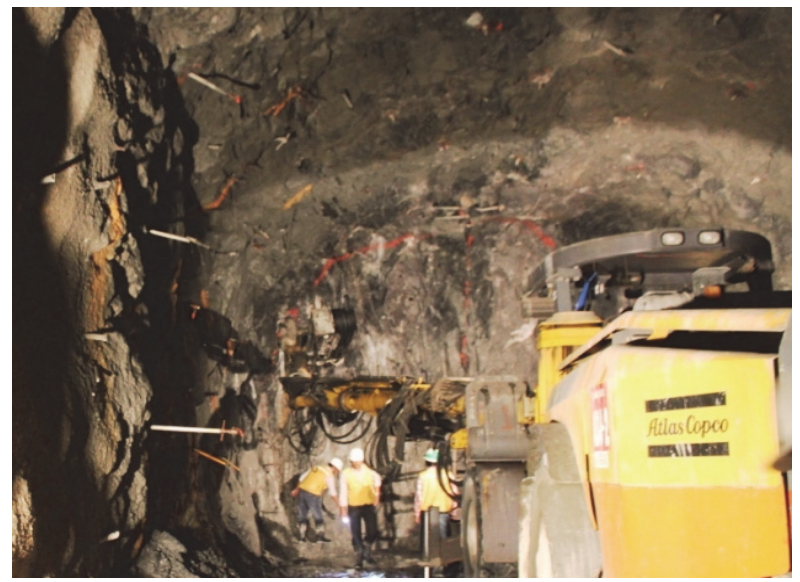

(6b)

Fig6. Installation of packer and bolts; (6a) during and (6b) after installation.

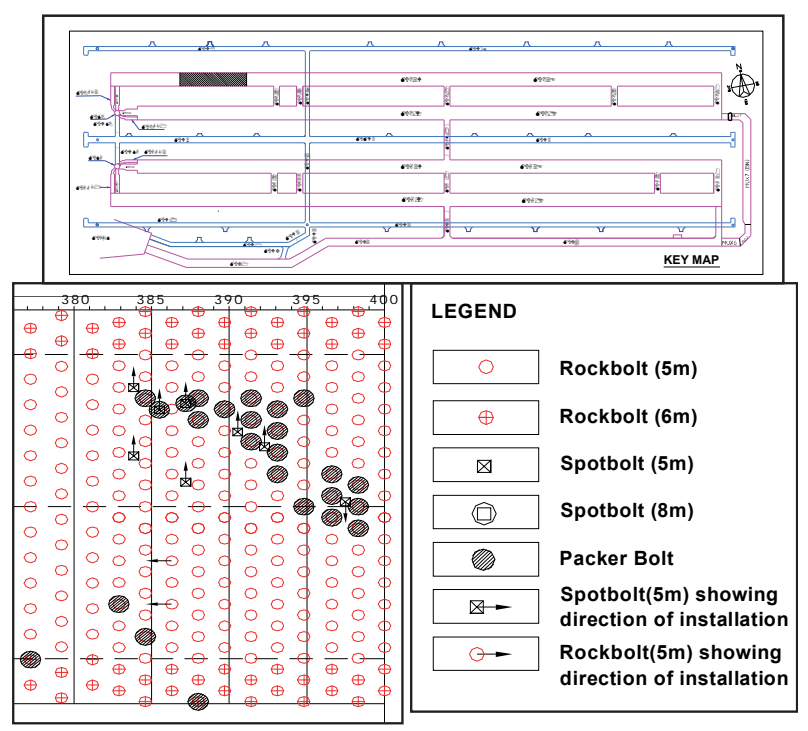

Fig.7. Cavern area with Packer and bolts installed

The rebar remains totally within the tunnel/cavern wall without any projection outside the hole. So pull out test, to check strength of the rock bolts, could not be performed on these bolts. However, total encapsulation with cement grout ensures sufficient strength of bolts. Also, these bolts were 
installed intermittent between regular bolts (Fig.7). The testing results of regular bolts with similar installation methodology without packers provided satisfactory results. Also, the load bearing effectiveness of the bolts were complimented by instrumentation data. The convergences observed in areas with packer bolts were within safe limits.

\section{CONCLUSIONS}

The method of installation of packer + bolt in water bearing zone served the dual purpose of rock supporting as well as grouting the leaking holes and surrounding rock mass. This indigenous method, with existing logistics, helped to successfully handle difficult situation of rock support under seepage conditions. The method aided in completing safe excavation of the project without any additional cost/time implication on account of rock support in water bearing zone.

Thus, the adapted method is one of the technocommercial solutions for rock support in water bearing zones and would play an important role for future projects of similar nature.

\section{ACKNOWLEDGMENT}

The authors wish to acknowledge the support rendered by the subsurface projects team and wish to place on record their thanks to the management of EIL for granting permission to publish the paper.

\section{REFERENCES}

[1] E.Amantini, F.Cabon and A.Moretto, "Groundwater management during the construction of underground hydrocarbon storage in rock caverns," In: Loredo, J. \& Pendás, F.: Mine Water 2005 - Mine Closure. - Oviedo (University of Oviedo), pp311-315.

[2] G. Anagnostou, "Tunnel stability and deformations in water-bearing ground," Keynote Lecture Eurock 06, ISRM Symposium on Multiphysics coupling and long term behaviour in rock mechanics, Belgium 2006.

[3] S. Pal, G.Kannan, and A. Nanda, " Handling ground water ingress in underground storage cavern," Proceedings Fifth Indian Rock Conference, New Delhi November 2014

[4] S.Pal, G.Kannan, V.Shahri and A.Nanda, "Ground water management for large underground storage caverns," in Engineering Geology for Society and Territory-Vol. 6, Springer International Publishing, 2015, pp 921-925. 